\title{
Comparison Of Different Anesthetic Techniques Used For Geriatric Patients Who Underwent TUR-P Operation: Single Center Experience
}

\section{Research}

Keywords:

Posted Date: January 4th, 2021

DOl: https://doi.org/10.21203/rs.3.rs-49635/v2

License: (c) (1) This work is licensed under a Creative Commons Attribution 4.0 International License. Read Full License 


\section{Abstract}

The authors have requested that this preprint be withdrawn due to erroneous posting.

\section{Full Text}

The authors have withdrawn this preprint from Research Square. 